\title{
A Review of Weapon Choice in Violent and Sexual Crime
}

\author{
Paul Dawson ${ }^{1}$, Alasdair M. Goodwill ${ }^{2}$ \\ ${ }^{1}$ School of Psychology, University of Birmingham, Birmingham, UK \\ ${ }^{2}$ Department of Psychology, Ryerson University, Toronto, Canada \\ Email: paul_dawson01@yahoo.co.uk
}

Received August 15 ${ }^{\text {th }}$, 2012; revised September 16 ${ }^{\text {th }}$, 2012; accepted September $23^{\text {rd }}$, 2012

\begin{abstract}
The concept that weapon choice and use may play a valuable role in differentiating between offenders is one that has not been well explored in current criminological or psychological thinking. The key aim of the current paper is to discuss the role of weapon choice and use in the application of offender profiling. Relevant research is identified though a literature review: initially considering a broad range of offences and then narrowing the focus on the specific case of violent and sexual offences. The review highlights several key findings which are then conceptualised through the offender profiling literature. In the discussion, the paper argues that there is considerable merit in the consideration of weapons within profiling violent and sexual offenders and concludes with proposed dimensions (planning and emotional use of the weapon) that illustrate the range of motivations that may aid in discriminating offenders.
\end{abstract}

Keywords: Weapon; Violence; Sexual Offences; Offender Profiling

\section{Introduction}

Weapon use in sexual and violent offences is a key consideration for police agencies and governments alike (Home Office, 2011). For the current paper, a weapon is defined as "an object used to cause or threaten injury to another”. Prevalence data pertaining to weapon enabled crime exists for England and Wales through Home Office statistical releases utilising both public survey and police statistics. For example, in the year ending March 2012, 51 per cent of attempted murders, 22 per cent of robberies, and one percent of rapes involved a knife or sharp instrument (ONS, 2012).

Prevalence data is collected in many countries (Catalano, 2005; Home Office, 2011; Australian Bureau of Statistics, 2004) and is valuable for understanding trends, developing policies or preventative strategies and the like. However, it reveals little on the motivations or whether weapon type has the ability to differentiate between offenders.

The question at hand is whether examining weapon use may benefit police or criminal investigations. This is a question that has not received adequate investigation: there is a paucity of weapon enabled research in current criminological and psychological thinking. As an example-a recent review conducted by Brennan and Moore (2009) was a valuable step forward relating to the history and theory of weapons, although did not cover the potential value of examining weapon use within a police context. Furthermore, the Crime Classification Manual (Douglas, Burgess, Burgess, \& Ressler, 2006), one of the most comprehensive texts concerning the classification of crime lacks an in-depth discussion regarding weapon use and what it may mean for the police.

One area where weapon use has been previously discussed beyond that of prevalence is within the offender profiling literature. There have been a number of psychological of investigative typologies that incorporate weapon use to varying degrees. The most notable of the psychological based typologies are Canter, Bennel, Alison and Reddy (2003) and Salfati and
Taylor's (2006) multidimensional scaling thematic representations of stranger rape and sexual assault, respectively. From an investigative viewpoint the Massachusetts Treatment Center's (MTC: R3) (Knight, Warren, Reboussin, \& Soley, 1998) classification system for sexual offenders and Groth's (1979) power and anger typology have been recently used the by Federal Bureau of Investigation (Hazelwood \& Burgess, 1987) for application to offender profiling. The organised/disorganised split has some consideration of the weapon (Ressler, Burgess, \& Douglas, 1988). While it is not the remit of the paper to critically evaluate offender profiling, a consideration of these typologies and how they incorporate weapon use will be valuable in supplementing discussions regarding the underlying motivetion of weapon use.

This paper seeks to go beyond prevalence data and explore the motivational, demographic and psychological aspects of offender weapon use. The aim is to examine the potential value for criminal investigations in considering the use of weapons within sexual and violent offenders.

\section{Methodology and Results}

A search of the literature was conducted to examine the issue of weapon use and offenders. The electronic sources included Swetswise, Ingenta, Silverplatter, Cambridge Scientific Abstracts and Zetoc. The basic search terms used in each were "weapon use", "weapon choice", "weapon \& offender" and "rape \& weapon". A wide range of articles were identified through the searches conducted. The results can be grouped into a number of key themes that we now turn to.

\section{Youth Violence and Weapon Use}

A number of identified research studies examined weapon use within youth samples reporting weapon to be relatively common (Barlas \& Egan, 2006; McCluskey, McCluskey, \& Bynum, 2006; Thurnherr, Michaud, Berchtold, Akre, \& Suris, 
2009; Simon, Crosby, \& Dahlberg, 1999). Kuntsche and Klingemann (2004) examined weapon carrying in a representative sample of 1549 Swiss school pupils reporting that $17 \%$ had taken a weapon to school. Clubb et al. (2001) reported that of 6400 US ethnic minority pupils, 30\% had used weapons in fights. Adolescents who reported living full-time with a parent or parent figure, and those who reported religious observance or beliefs, were less likely to report violence involvement. All violence related behaviors were more common among male than female adolescents.

Malek, Chang and Davis (1998) examined 297 cases of school fights involving 7th grade students in three US communities. One or more weapons were reported to have been used within $43 \%$ of all reported fights. Those fights with more than 5 individuals, intoxicated students or gang involvement were the predictors of both weapon use and injury. Benda and Tollett (1999) examined 224 criminal youths in the United States examining factors associated with reconviction. Carrying a weapon was one of the main predictors of reconviction. Hill, Howell, Hawkins and Battin-Pearson (1999) examined youths and gangs. The key risk factors for gang involvement were neighbourhood, family, school, peer and individual differences.

Langstrom and Grann (2000) found that sexual recidivism of adolescents was associated with index offence weapon use, previous criminality, psychopathology and conduct disorder. They also identified weapon use as a key predictor of future diagnosis of conduct disorder in adolescence. Conduct disorder is characterised by behavioural and emotional problems and can be defined as a repetitive and persistent pattern of behaviour in which the basic rights of others and of major society are violated (APA, 1994). In order to receive a diagnosis the symptoms must cause significant impairment to the social, academic or occupational functioning and be present within specific timeframes. The major symptoms include:

- aggression to people or animals (bullying, cruelty to animals and the use of a weapon);

- destruction of property (deliberate);

- deceitfulness or theft (broken into others property);

- serious violations of rules (run away from home).

Conduct disorder has clear associations with criminality (due to the behaviours such as theft, weapon use, and general anti-social behaviour) but also co-morbidity with other problems such as Attention Deficit Hyper Disorder (Loeber, Burke, Lahey, Winters, \& Zera, 2000) or substance misuse (Boys et al., 2003). This has important implications in the differentiation of offenders by weapon use as the onset of criminal behaviour, weapon use and conduct disorder are seemingly correlated. Indeed, criminological research indicates that adult offenders that are prolific offenders are significantly more likely to have begun their criminal career at a younger age than the general offending population (Farrington, 2005).

\section{Domestic Violence}

The search revealed a number of relevant articles concerned with weapon use in cases of domestic violence. Sorenson and Wiebe (2004) examined 417 women in 600 shelters reporting that words, hands and feet were the most common method of assault. Thompson, Saltzman and Bibel (1999) reported that weapon use was positively related to injury levels in domestic violence. Murrell, Merwin, Christoff and Henning (2005) explored weapon use in 362 male domestic violence perpetrators.
Specifically the self-report of viewing parental violence incurporating weapons as a child was explored. Men who reported witnessing threat or the use of a weapon in parental violence were more likely than not to have threatened to use a weapon themselves. However, in the sample most men that used weapons did not report witnessing such weapon related violence as a child.

Haugen, Slungård and Schei (2005) examined 162 females in a sexual assault health service between 2000 and 2003 finding that type and severity of the sexual assault did not differ significantly according to the victim-perpetrator relationship. However, the victims of known offenders only reported lifethreatening violence and the use of a weapon. Research also found that domestic violence offenders that used a weapon during their offence were more likely to be arrested than individuals who did not (Houry, Reddy, \& Parramore, 2006; Hassani, Houry, Parramore, Heron, \& Kellermann, 2004).

Greene, Maas, Carvalho and Raven (1999) examined gender-specific patterns of male and female victims of assault. Specifically, a cohort of 91 female assault cases was compared with a control group of 706 males with similar injuries resulting from blunt assault trauma. Females were more likely to be admitted with soft tissue injury only but no fracture, less likely to be assaulted with a weapon, and unlikely to be involved in an altercation, gang violence, arrest, or robbery. Females were also less likely than males to be injured while intoxicated. The incidence of specific injury patterns and outcomes, however, were similar between the male and female groups.

\section{General Violence and Weapons}

Wintemute, Drake, Beaumont, Wright and Parham (1998) examined the previous criminal record of individuals purchasing handguns to explore future criminal behaviours. Of the 5923 authorised purchasers, 3128 had at least one conviction prior to handgun purchase. In a 15-year follow-up study the handgun purchasers with at least one prior conviction were more than seven times as likely as those with no prior criminal history to be charged with a new offence after handgun purchase. Those with two or more prior convictions for violence were at greatest risk for offences of murder or non-negligent manslaughter, forcible rape, robbery and aggravated assault. This link between weapons and an increased likelihood of recidivism is supported elsewhere (Ministry of Justice, 2011; Huebner, Varano, \& Bynum, 2007).

Pratt and Deosaransingh (1997) examined gender differences for homicides in the United States. Females were more likely to be killed by their spouse of intimate partner, where men were more likely to be killed by strangers. A higher percentage of women than men were killed with a blunt object, a personal weapon (i.e., fists, feet, and teeth), or other weapon (25\% versus $11 \%)$. Men were more likely than women to be killed by a firearm, in a public place and whilst a crime was being committed.

Moskowitz, Laraque, Doucette and Shelov (2005) examined the relationships between US youth homicide victims aged zero to 19 years between 1976 and 1999. A total of 70,258 victims were studied. Murdered girls were 3.6 times more likely to have been killed by family members and 21.3 times more likely to have been killed by intimate partners than murdered boys. Handguns were more likely to be used during homicides committed by strangers. 
Smith (2003) examined the nature of robbery in England and Wales based on an investigation of over 2000 crime reports and witness statements across seven police areas. Weapons were present in a third of all robberies-particularly when the offender used a confrontational victim approach. Knives were the most frequently used weapon type, being used in 1 in every 5 personal robberies.

Wells and Horney (2002) examined over 2000 violent and potentially violent events described by offenders to assess the role of weapons. The authors reported that the offenders intent to injure did not appear to play a role in determining the need for a weapon and firearm attacks overall reduced the risk of injury. Kleck and DeLone (1993) conducted logistic regression analysis on over 4500 robbery incidents reported in the 19791985 period. Unarmed physical force against the robber and trying to get help, attract attention, or scare the robber away generally increased the likelihood of victim injury. The robber's possession of a gun appeared to inhibit victim resistance and so perversely, the offender using a gun reduced the probability of victim injury. However, even controlling for victim resistance, gun possession was associated with a lower rate of injury to the victim. Robbers with handguns were much more likely to complete their robberies than those with knives or other weapons and unarmed assailants. However, once an injury occurred, those with a weapon were more likely to cause greater levels of harm. This seems to indicate the functional value of weapons, namely to control victims and facilitate completion of the robbery.

\section{Murder-Suicide, Child Homicide and Filicide}

A number of studies examined weapon use within homicide-suicide (a murder followed by the suicide of the murderer).

Easteal (1994) examined Australian homicide-suicides reporting that if the offender was an estranged male from his partner, born outside of Australia, who used a gun as the weapon and killed more than one victim, or was older with an ailing wife, he was more apt to commit suicide. Lecomte and Fornes (1998) examined this crime within Paris and its suburbs between 1991 and 1996. During the six-year study period, there were 56 cases involving 133 victims. In 45 events (80\%), the offenders used a gun for both the homicide and suicide. A knife was used in only four murders, strangulation in four other cases, with poisoning, arson, or beating occurring in one case each. In nine cases, the offender used a different weapon for the suicide than for the murder. Among firearms, handguns were more likely to be used than shotguns.

Lyman et al. (2003) investigated the epidemiology of child homicide in Jefferson County, Alabama for children that were born and died between 1988 and 1998. Homicides primarily resulted from an angry impulse (61\%), with hands the most common weapon (61\%). This apparently links high emotion such as anger to impulsive personal attacks, where planned use of a weapon is not apparent. Lewis, Baranoski and Buchanan (1998) reported 60 cases of maternal filicide and weapons were used by one in four cases. Psychotic women were 11 times more likely to kill with a weapon.

\section{Cross Cultural Comparisons}

A small number of studies conducted cross-cultural investigations into weapon use. Eisner and Wikström (1999) com- pared two European capitals (Stockholm and Basle) reporting that the presence of weapons increased the risk of violent events. Friday, Dussich, Okada and Yamagami (2000) compared a US and Japanese sample reporting that US participants were more likely to state that they would use weapons in response to a threat.

Boots and Heide (2006) investigated 208 cases of parricide involving weapon use; $40 \%$ were firearms, knives $21 \%$ and other objects (12\%). Cultural differences were evident in that US parricides were more likely to use firearms (49\% vs. $21 \%$ ) and multiple weapons (14\% vs. $9 \%$ ) than non-US parricides, which showed a higher frequency of knife (27\% vs. $18 \%)$ and blunt weapon use (19\% vs. $9 \%)$.

Rogde, Hougen and Poulsen (2000) examined homicide by sharp weapons in two Scandinavian capitals between 1985 and 1994. In total, 33\% of homicides used a knife. Female victims on average received lesions in three to four anatomical regions compared to male victims who received most frequently in one. The authors hypothesise that a possible explanation for this was that the female victims more often were killed by someone closely related to them, and that multiple wounding was evident when the perpetrator was emotionally related to the victim.

\section{Weapon Use against the Elderly}

Bachman (1998) examined violence against the elderly over a two-year period. It was found that older victims, particularly women, were more likely to sustain injuries as the result of a violent attack using a weapon and more likely to require medical care for these injuries. Safarik, Jarvis and Nussbaum (2002) and Safarik and Jarvis (2005) examined the homicide of elderly women. These studies devised a scale of injury and reported that there was a predominate use of personal weapons (feet, fists) and firearms were only evident in 3\% of cases. In the cases present, $10 \%$ of offenders to conduct the sexual murder of elderly females brought weapons to the scene.

\section{Weapon Use in the Mentally Disordered}

A number of studies examined the weapon use of individuals with mental disorders, examining whether symptom type was associated with weapon type. Stueve and Link (1997) reported that weapon use was elevated in psychotic and bi-polar community based individuals with mental illness. Swanson, Swartz and Van Dorn (2006) conducted a large-scale study into the violent behaviour of 1410 schizophrenic patients finding that positive symptoms were associated to high levels of violence, including the use of weapons.

Michie and Cooke (2006) examined 250 Scottish prisoners who were subject to a range of psychological assessments. A nine-question tool, interviews, the Psychopathy ChecklistRevised (PCL-R) and a number of other scales were used with the aim of developing a hierarchical model of violence. Two factors provided the best fit to the violent data, namely "violence with a weapon" and "violence without a weapon". Violence with a weapon was particularly associated with psychopathy, a history of childhood violence and the frequency of aggressive fantasies. Violence without a weapon was associated with level of anger (NOVACO scale), the Barratt impulsivity scale and age at interview. The authors likened this distinction to predatory aggression (weapon use) compared to affective aggression (non-weapon use). The authors also note that further 
work examining the difference choices of weapon (i.e. knives vs. guns) may be useful in further model refinement.

Catanesi et al. (2011) examined psychopathology and weapon choice, reporting a significant correlation between some mental disorder and weapons. A strong correlation was reported between delusional disorders and sharp weapons, whereas depressive disorders were more strongly associated with asphyxia. Organic disorders were highly correlated with the use of blunt weapons.

\section{Sexual Offenders and Weapon Use}

Greenfeld (1997) examined a range of databases held by the US Bureau of Justice Statistics. Offenders were five times more likely to use a gun in the rape of a stranger $(10 \%)$ than in the rape of a family member (2\%). Rapes committed by AfricanAmerican offenders against African-American victims were about twice as likely as Caucasian against Caucasian rapes to involve the use of a gun or knife (14\% vs. $7 \%$ ). Interracial rapes were equally likely to use a gun or knife (22\%).

Woodhams, Gillet and Grant (2007) examined stranger juvenile sexual offences. In particular, how victim characteristics and the number of suspects affected the use of physical violence and the occurrence of penetration in 495 allegations of sexual assault. Victims experiencing penetrative offences were significantly younger than victims to receive no penetration. Group assaults were associated with a higher level of violence and penetration as compared to lone individual offenders. However, in this study victim age was not found to be associated with weapon use or number of assailants.

Beauregard and Leclerc (2007) interviewed serial sexual offenders whom discussed issues around control, intimidation and the functional value of weapons before, during and after their offence. Guay, Ouimet and Proulx (2004) studied individuals (sexual and non-sexual offenders) and their processing through the US Criminal Justice System (CJS). Weapon use was reported to be of principal importance, in that offenders using weapons were more likely to be treated more harshly and sent to custodial institutions. This seems to indicate that courts view weapon use as a measure of increased severity and substantial risk to the community. Accordingly, Bachman (1998) reported that the key factors that increased the likelihood of a rape being reported to the police were weapon use and severity of injury. In an examination of young sexual offenders $(n=46)$ in Sweden, Langstrom and Grann (2000) found recidivism was low (20\%) but significantly associated with previous criminality, conduct disorder, psychopathy and weapon use.

Brecklin and Ullman (2001) reported that alcohol use prior to rapes $(n=362)$ was associated with an outdoor assault, night-attack, stranger attack and increased victim resistance. There was no difference between pre-assault alcohol use and offender aggression or weapon use (11\% of alcohol and $10 \%$ non-alcohol rape groups). Coker, Walls and Johnson (1998) examined 213 female and 664 male victims of sexual assault in South Carolina between 1991 and 1994. On average, females received more injuries than males and were at significantly greater risk of severely violent, non-penetrative sexual assault, in offences involving multiple assailants, sodomy, weapon use, being kidnapped, stranger offender(s) and offender intoxication. Ruback and Ivie (1998) examined information about the rapes of 2526 adult females from the records of a rape crisis centre, finding that attacks by strangers were more likely to involve a weapon and to occur outdoors than were attacks by nonstrangers and victims were less likely to physically resist strangers than non strangers.

English, Retzlaff and Kleinsasser (2002) developed the Colorado Sex Offender Risk Scale. A sample of 494 sex offenders was followed for an average of 30 months. A risk scale was developed based upon criminal and therapeutic outcomes. The final risk scale included a range of factors such as previous youth convictions, denial in therapy, sexual deviance in therapy and weapon use during the crime. The risk scale provided significant relative risk ratios against program failure at 12 and 30 months for those using weapons during their offences.

Vinogradov, Dishotsky, Doty and Tinklenberg (1988) interviewed 63 adolescents accused of rape reporting that the "typical” rapist often had a criminal record and carried a weapon. Quinsey and Upfold (1985) examined adult male rapists that had been referred to a maximum-security psychiatric institution. Rapists were more likely to complete the rape when the attack was conducted in an inside location, with a weapon and not against a stranger.

Pino and Meier (1999) found that the rape of males were more likely to involve a weapon, although there was no gender differences regarding injury received. Cohen, Frenda, Mojtabai, Katsavdakis and Galynker (2007) reported offenders against children were less likely to use a weapon. Muram, Hostetler, Jones and Speck (1995) reported that sexual assaults versus females more often involved weapons and physical injury in comparison to young victims, indicating that weapon use may be associated to victim age.

\section{Motivations of Weapon Use}

As we have seen research pertaining to weapons would appear to be relatively broad in nature covering many crime types, although there has been some valuable research that may be of value to a police force (e.g. criminal history of weapon enabled offenders). Moving forward, while there has not been extensive research on weapon use within an offender profiling context, there has been several investigative and psychological typologies that incorporate weapon use. The most notable of the psychological based typologies are Canter, Bennel, Alison and Reddy (2003) and Salfati and Taylor's (2006) multidimensional scaling thematic representations of stranger rape and sexual assault, respectively. From an investigative viewpoint the Organised/disorganised (Ressler, Burgess, \& Douglas, 1988), the Massachusetts Treatment Center's (MTC: R3) (Knight, Warren, Reboussin, \& Soley, 1988) classification system for sexual offenders and Groth's (1979) power and anger typology have been recently adapted the Federal Bureau of Investigations (FBI) (Hazelwood \& Burgess, 1987) respectively, for application to offender profiling. These typologies, although approaching the topic from different perspectives do have considerable overlap in underlying theory. Therefore, rather than a series of separate discussions of each typology, the main underlying themes will be highlighted and discussed in relation to weapon use.

\section{Control of the Victim}

An element within a number of the typologies is the issue of achieving control and compliance of the victim. According to Canter, Bennel, Alison and Reddy (2003) offenders in the control domain view the victim as an inanimate object, one that 
needs to be trussed and controlled. The use of bindings, ropes, gags and a weapon are highlighted as behaviours demonstrating this theme. This view is shared by Salfati and Taylor (2006) whom also highlight behaviours designed to control the victim as an important discriminatory factor in their domain. In this respect, the weapon can relate to the enhanced control of the victim enabling the offence to be completed with greater ease. Salfati and Taylor further theorise that weapon use reflects a predominantly functional or instrumental behavioural aspect of the offence demonstrating the offender's need for control and characteristic of a planned offence. A so called organised offender would also be ascribed more likely to use a weapon to control and facilitate the crime (Ressler, Burgess, \& Douglas, 1988).

\section{Power and Intimacy}

The next theme is also predominantly instrumental in nature as a weapon is shown by the offender in order to gain power over the victim in an attempt to offer the offender a level of victim compliance in which they can pursue pseudo-intimacy with the victim. Hazelwood and Burgess's (1987) FBI typology, based on the work of Groth (1979), suggests power-reassureance offenders commit offences in an attempt to challenge their own sexual doubts and their own personal inadequacy. As such the offender may ask the victim to participate in the offence, though importantly, without any motivation to either degrade or harm the victim. According to Keppel and Walter (1999) serial offenders motivated by power-reassurance may begin their offences with no weapon but progress to bringing a weapon to better gain full compliance from the victim, without the need to excessively physically harm them. For these offenders, the hostile or aggressive use of a weapon and associated higher levels of physical violence could be seen as counter-productive to their overall aim of achieving pseudo-intimacy through power.

\section{Anger and Weapon Use}

Groth (1979) argues that anger plays an important psychological role in rape and is also a central aspect to each aforementioned typology. To relate the different psychological processes of anger to weapon use, anger is separated into general and targeted anger.

In terms of general anger, Salfati and Taylor (2006) describe a violent theme associated with a hostile frenzied attack in both rapists and sexual murderers. The key variables composing the violent theme were multiple wounding, non-controlled violence and the offender using a weapon from the crime scene. Interestingly, they reported that rapists were more likely to bring a weapon to the crime scene ( $43 \%$ vs. $14 \%)$, whereby sexual murders were more likely to use a weapon from the crime scene (35\% vs. $5 \%$ ). The lack of a weapon in the sexual murderer sample may indicate the impulsivity and highly emotional offence of sexual murder.

Knight, Warren Reboussin and Soley (1988) describe a pervasive anger domain within the MTC: R3 in which offenders have enduring "global” anger "against the world", alongside a history of antisocial aggressive behaviours. As such, offenders express their anger though their rapes and victims are likely to receive a high level of injury. The power assertive domain involves an element of planning and physical aggression and is viewed as an expression of virility, masculinity and dominance on the part of the offender. Keppel and Walter (1999) state that regarding sexual murder this type of offender will often use a weapon and view it as an extension of their personality, carrying an element of symbolic importance to deliberately hurt and intimidate the victim.

Whereas the previous section considered general, or global, anger towards victims, there are offenders that have specific/targeted anger towards their victim; either as a specific person (e.g. girlfriend, prostitutes, etc.) or a particular misogynistic hatred of females for example. Canter, Bennel, Alison and Reddy (2003) found that factors such as tearing clothing, single and multiple acts of violence, demeaning behaviours, anal sex and verbal insults were commonly associated with each other composing a thematic region dubbed hostility. Likewise, Salfati and Taylor (2006) proposed a theme associated with violent behaviours such as anal penetration and the use of foreign objects in penetration, termed exploit. However, no definition of foreign object was provided, but there could be some crossover between the use of foreign objects and weapons as it is possible that some weapons could be used in this sexual manner. Previous literature indicates the correlation between head/face wounding, multiple wounding and a relationship to the victim (Salfati \& Canter, 1999; Haugen, Slungard, \& Schei, 2005).

Of relevance here is the term "overkill" that Douglas, Burgess, Burgess and Ressler (2006) describe as excessive violence that is personal against the victim, with anger as the common underlying drive. The example being a husband that severely bludgeons and stabs his wife 20 times, in comparison to a burglar whom they posit would not use such violence. They argue that overkill, especially to the face is often an attempt to dehumanise the victim-but may also indicate the killer knows the victim or represents a specific person.

Groth (1979) defined the anger-retaliatory domain, which included an expression of anger towards females, including a disregard for the victim, selfish behaviours and strong violence delivered through a perceived explosive retribution. In terms of sexual murder this type is more likely to assault with fists or weapons of opportunity, indicating an emotional and impulsive element to the crime. The MTC: R3 incorporates a vindictiveness domain that involves high levels of misogynistic anger directed and focused on women. The primary aim for such offenders is to degrade, harm and to humiliate women. In such cases of targeted anger, it could be inferred that weapon use would be used deliberately to harm and terrorise the victim. However, the choice of weapon could be relatively impulsive with offenders using any available object found at the crime scene.

\section{Opportunism}

Both the MTC: R3 (Knight, Warren, Reboussin, \& Soley, 1988) and FBI (Hazelwood \& Burgess, 1987) typologies involve an element of opportunism. Such crimes are influenced by contextual and environmental factors as opposed to deepseated motivations. These seem to be criminally minded individuals, of which sexual crimes are but one element of an overall criminality and anti-social nature. It is unclear whether these individuals are more probable to generally carry weapons and then utilise them during an opportunistic offence or offend when opportunities arise utilising any weapon they can fashion at the crime scene. 


\section{Deviant Use}

The final theme to be discussed from the typologies relates to the extreme of both instrumental and expressive factors. Groth (1979) discusses the anger-excitation motivation stating that it relates to a strongly pre-planned offence whereby the offender inflicts pain and terror on the victims in order to derive pleasure. The sexual theme within the MTC: R3 classification similarly assumes that some form of sexual preoccupation with sadistic fantasies serves to motivate the rape. Within the MTC: R3 highly sexual offences are sub-divided into sadistic and nonsadistic. In both the FBI and MTC: R3 typologies the sadistic elements would be likely to increase the use of weapons both to fully control the victim to enable the playing out of the fantasy and for the sadistic violence directed at the victim. As such, weapons go far beyond a functional use and are more likely utilised to enable the expression of deep psychological motivetions for power, control and sadism.

\section{Discussion}

The paper has sought to identify literature to inform thinking about the issue of weapon use both in sexual and violent crimes within a police context. It is clear that weapon use, while not the focus of a considerable amount of research itself, is discussed within a variety of offender and offence types. This paper has sought to bring this research together, identify a gap and to progress the topic forward. In consideration of the results from the literature and how weapon use has been viewed by a number of typologies the following dimensions of weapon use are proposed. These illustrate the range of offenders and motivations where weapon use may aid in discriminating offenders.

\section{Evidence of Planning (Opportunism and Control)}

Evidence of planning, be this high or low, emerged as a theme underpinning weapon use. This was found in a variety of the samples. High planning demonstrating forethought in bringing a weapon and a facilitative or controlling element to the crime compared to crimes of opportunity. Such a theme is consistent within an organised/disorganised offender and instrumental violence (Bartol, 1991).

\section{Emotional Use of a Weapon (Anger and Power)}

Weapon choice and use can also demonstrate an offenders' emotional expressiveness, feelings of inadequacy and anger towards the victim. In some research the weapon moves beyond a utility function to facilitate a crime and appeared to be related to an intent to harm the victim. This is consistent with expressive violence (Salfati, 2000). A practical example would be an offender brandishing a hammer or axe as compared to a knife in order to elicit terror and increase the damage potential. The choice of weapon in these instances may indicate differential motivations and thus generate discriminatory offender characteristics able to aid in offender profiling.

\section{Conclusion}

The above dimensions have implications for differentiating between offender characteristics, for example; levels of impulsivity, evidence of planning, anger and aggression, basic demographics and previous convictions. For example, offenders using a weapon as a strategy for control or to facilitate the crime would be, it is hypothesised, have a longer and more extensive criminal career than the other weapon dimensions. Those within the emotional use would be likely to have a violent criminal history.

While many aspects of a criminal career will be in constant development and subject to learning and other environmental factors, it is proposed that the underlying motivations of using a weapon are likely to remain static. Research on this topic would be valuable. Other unexplored concerns regarding weapon use would be issues such as the transition from youth to adult weapon use, different choices of weapon, escalation and deescalation and consistency in weapon use. These are all key areas, not only academically but also of practical use to police investigations.

The current paper has examined the use of weapons within a number of crime types, but with a specific focus on sexual crimes. This research has been discussed and considered within an offender-profiling context. Key results have been presented from the literature review and proposed motivations underpinning the use of a weapon. The topic of weapon use has not been explored adequately in the previous literature-while the present study is far from comprehensive, it can hopefully lay some important groundwork to extend research on the issue of weapon use.

\section{REFERENCES}

American Psychiatric Association (1994). Diagnostic and statistical manual of mental disorders (4th ed.). Washington DC: American Psychiatric Association.

Australian Bureau of Statistics (2004). Sexual assault in Australia: A statistical overview. Canberra: Australian Bureau of Statistics.

Bachman, R. (1998). The factors related to rape reporting behavior and arrest: New evidence from the National Crime Victimization Survey. Criminal Justice and Behavior, 25, 88-29. doi:10.1177/0093854898025001002

Barlas, J., \& Egan, V. (2006). Weapons carrying in British teenagers: The role of personality, delinquency, sensational interests, and mating effort. Journal of Forensic Psychiatry and Psychology, 17, 53-72. doi:10.1080/14789940500407692

Bartol, C. (1991). Criminal behaviour: A psychosocial approach. (3rd ed.). Englewood Cliffs, NJ: Prentice Hall.

Beauregard, E., \& Leclerc, B. (2007). An application of the rational choice approach to the offending process of sex offenders: A closer look at the decision-making. Sex Abuse, 19, 115-133.

Benda, B. B., \& Tollett, C. L. (1999). A study of recidivism of serious and persistent offenders among adolescents. Journal of Criminal Justice, 27, 111-126. doi:10.1016/S0047-2352(98)00051-8

Boots, D., \& Heide, K. (2006). Parricides in the media: A content analysis of available reports across cultures. International Journal of Offender Therapy and Comparative Criminology, 50, 418-415. doi:10.1177/0306624X05285103

Boys, A., Farrell, M., Taylor, C., Marsden, J., Goodman, R., Brugha, T., Bebbington, P., Jenkins, R., \& Meltzer, H. (2003). Psychiatric morbidity and substance use in young people aged 13 - 15 years: Results from the child and adolescent survey of mental health. British Journal of Psychiatry, 182, 509-517. doi:10.1192/bjp.182.6.509

Brennan, I. R., \& Moore, S. C. (2009). Weapons and violence: A review of theory and research. Aggression and Violent Behavior, 14, 215-225. doi:10.1016/j.avb.2009.03.003

Brecklin, L. R., \& Ullman, S. E. (2001). The role of offender alcohol use in rape attacks: An analysis of national crime victimization survey data. Journal of Interpersonal Violence, 16, 3-21. doi:10.1177/088626001016001001

Canter, D. V., Benell, C., Alison, L., \& Reddy, S. (2003). Differen- 
tiating sex offences: A behaviourally based thematic classification of stranger rapes. Behavioral Sciences and the Law, 21, 157-174. doi:10.1002/bsl.526

Catanesi, R., Carabellese, F., Troccoli, G., Candelli, C., Grattagliano I., \& Fortunato, F. (2011). Psychopathology and weapon choice: A study of 103 perpetrators of homicide or attempted homicide. Forensic Science International, 209, 149-153.

Catalano, S. M. (2006). National crime victimization survey, criminal victimization 2005. Washington DC: Bureau of Justice Statistics, US Department of Justice.

Clubb, P. A., Browne, D. C., Humphrey, A. D., Schoenbach, V., Meyer. B., \& Jackson, M. (2001). Violent behaviors in early adolescent minority youth: Results from a middle school youth risk behavior survey. Maternal and Child Health Journal, 5, 225-235. doi:10.1023/A:1013076721400

Cohen, L. J, Frenda, S., Mojtabai, R., Katsavdakis, K., \& Galynker, I. (2007). Comparison of sexual offenders against children with sexual offenders against adolescents and adults: data from the New York State Sex Offender Registry. Journal of Psychiatric Practice, 13, 373-384. doi:10.1097/01.pra.0000300123.83945.76

Coker, A. L., Walls, L. G., \& Johnson, J. E. (1998). Risk factors for traumatic physical injury during sexual assaults for male and female victims. Journal of Interpersonal Violence, 13, 605-620. doi:10.1177/088626098013005004

Douglas, J. E., Burgess, A. W., Burgess, A. G., \& Ressler, R. K. (2006) Crime classification manual. A standard system for investigating and classifying violent crimes. Hoboken: John Wiley \& Sons.

Ressler, R. K., Burgess, A. W., \& Douglas, J. E. (1988). Sexual homicide: Patterns and motives. New York: Free Press.

Easteal, P. (1994). Homicide-suicides between adult sexual intimates: An Australian study. Suicide and Life Threatening Behavior, 24, 140-151.

Eisner, M., \& Wikström, P. O. (1999). Violent crime in the urban community: A comparison of Stockholm and Basel. European Journal on Criminal Policy and Research, 7, 427-442. doi:10.1023/A:1008782232545

English, K., Retzlaff, P., \& Kleinsasser, D. (2002). The Colorado sex offender risk scale. Journal of Child Sexual Abuse, 11, 77-95. doi:10.1300/J070v11n02_05

Farrington, D. P. (2005). Integrated development and life-course theories of offending: Advances in criminological theory. Piscataway, $\mathrm{NJ}$ : Transaction Publishers.

Fingerhut, L., Cox, C., \& Warner, M. (1998). International comparative analysis of injury mortality: Findings from the ice on injury statistics. Advance Data, 303, 1-20.

Friday, P. C., Dussich, J. P. J., Okada, T., \& Yamagami, A. (2000). Weapon ownership and the willingness to respond to threats with violence: The United States and Japan. International Journal of Offender Therapy and Comparative Criminology, 44, 164-177. doi:10.1177/0306624X00442003

Groth, N. A. (1979). Men who rape: The psychology of the offender. New York: Plenum.

Greene, D., Maas, C. S., Carvalho, G., \& Raven, R. (1999). Epidemiology of facial injury in female blunt assault trauma cases. Archives of Facial Plastic Surgery, 1, 288-291. doi:10.1001/archfaci.1.4.288

Greenfeld, L. A. (1997). Sex offenses and offenders: An analysis of data on rape and sexual assault. Washington DC: Bureau of Justice Statistics.

Guay, J. P., Ouimet M., \& Proulx, J. (2004). Criminal justice institutional referrals and selections: A comparative portrait of sexual aggressions and aggressors. International Journal of Offender Therapy and Comparative Criminology, 48, 330-346. doi:10.1177/0306624X04263867

Hassani D., Houry, D., Parramore, C., Heron S., \& Kellermann, A. (2004). Is the presence of children at the scene of domestic violence incidents associated with increased violence, alcohol intoxication, or weapon use? Annals of Emergency Medicine, 44, S96. doi:10.1016/j.annemergmed.2004.07.312

Haugen, K., Slungard, A., \& Schei, B. (2005). Sexual assault against women-injury pattern and victim-perpetrator relationship. TidsskrNor-Laegeforen, 15, 3424-7.
Hazelwood, R., \& Burgess, A. (1987). Practical aspect of rape investigation: A multidisciplinary approach. New York: Elsevier.

Hill, K. G., Howell, J. C., Hawkins, J. D., \& Battin-Pearson, S. R. (1999). Childhood risk factors for adolescent gang membership: Results from the seattle social development project. Journal of Research in Crime and Delinquency, 36, 300-322. doi:10.1177/0022427899036003003

HM Government (2011). Ending gang and youth violence: Cross-government report. London: Home Office.

Home Office (2011). Crime in England and Wales 2010/11. Findings from the British crime survey and police recorded crime. Home Office Statistical Bulletin.

Houry, D., Reddy, S., \& Parramore, C. (2006). Characteristics of victims coarrested for intimate partner violence. Journal of Interpersonal Violence, 21, 1483-1492. doi:10.1177/0895904805293483

Huebner, B. M., Varano, S. P., \& Bynum, T. S. (2007). Gangs, guns, and drugs: Recidivism among serious, young offenders. Criminology \& Public Policy, 6, 187-221. doi:10.1111/j.1745-9133.2007.00429.x

Kleck, G., \& DeLone, M. A. (1993). Victim resistance and offender weapon effects in robbery. Journal of Quantitative Criminology, 9, 55-81.

Keppel, R. D., \& Walters, R. (1999). Profiling killers: A revised classification model of understanding sexual murder. International Journal of Offender Therapy and Comparative Criminology, 43, 417-437. doi:10.1177/0306624X99434002

Knight, R. A., Warren, J. I., Reboussin, R., \& Soley, B. J. (1998). Predicting rapist type from crime-scene variables. Criminal Justice and Behavior, 25, 46-80. doi:10.1177/0093854898025001004

Kuntsche, E. N., \& Klingemann, H. K. (2004). Weapon carrying at Swiss schools? A gender-specific typology in context of victim and offender related violence. Journal of Adolescent Health, 27, 381-393. doi:10.1016/j.adolescence.2004.02.003

Langstrom, N., \& Grann, M. (2000). Risk for criminal recidivism among young sex offenders. Journal of Interpersonal Violence, 15, 855-871. doi:10.1177/088626000015008005

Lecomte, D., \& Fornes, P. (1998). Homicide followed by suicide: Paris and its suburbs, 1991-1996. Journal of Forensic Sciences, 43, 760764.

Lewis, C. F., Baranoski, M. V., \& Buchanan, J. A. (1998). Factors associated with weapon use in maternal filicide. Journal of Forensic Sciences, 43, 613-618.

Loeber, R., Burke, J. D., Lahey, B. B., Winters, A., \& Zera, M. (2000). Oppositional defiant and conduct disorder: A review of the past 10 years, Part I. Journal of the American Academy of Child and Adolescent Psychiatry, 39, 1468-1484.

doi:10.1097/00004583-200012000-00007

Lyman, J. M., McGwin, G., Malone, D. E., Taylor, A. J., Brissie, R. M., \& Davis, G. (2003). Epidemiology of child homicide in Jefferson County, Alabama. Child Abuse and Neglect, 27, 1063-1073. doi:10.1016/S0145-2134(03)00166-2

Malek, M. K., Chang B. H., Davis, T. C., Malek, M. K., Chang, B. H., \& Davis, T. C. (1998). Self-reported characterization of seventhgrade students' fights-A public health emergency. Journal of Adolescent Health, 23, 103-109. doi:10.1016/S1054-139X(98)00020-2

McCluskey, C. P., McCluskey, J. D., \& Bynum, T. S. (2006). Early onset offending and later violent and gun outcomes in a contemporary youth cohort. Journal of Criminal Justice, 34, 531-541. doi:10.1016/j.jcrimjus.2006.09.008

Ministry of Justice (2011). Hazards of different types of reoffending. Ministry of Justice Research Series.

Moskowitz, H., Laraque, D., Doucette, J. T., \& Shelov, E. (2005). Relationships of US youth homicide victims and their offenders, 1976-1999. Archives of Paediatrics \& Adolescent Medicine, 159, 356-361. doi:10.1001/archpedi.159.4.356

Michie, C., \& Cooke, D. J. (2006). The structure of violent behavior: A Hierarchical model Glasgow Caledonian university; Glasgow Caledonian University, the Douglas Inch Centre. Criminal Justice and Behavior, 33, 706-737. doi:10.1177/0093854806288941

Muram, D., Hostetler, B. R., Jones, C. E., \& Speck, P. M. (1995). Adolescent victims of sexual assault. Journal of Adolescent Health, 17, 372-375. doi:10.1016/1054-139X(95)00097-C 
Murrell, A. R., Merwin, R. M., Christoff, K. A., \& Henning, K. R. (2005). When parents model violence: The relationship between witnessing weapon use as a child and later use as an adult. Behavior and Social Issues, 14, 128-133.

Office of National Statistics (2012). Statistical bulletin: Crime in England and Wales, Quarterly First Release to March 2012. Part of Crime Statistics, period ending March 2012. ONS.

Pino, N. W., \& Meier, R. F. (1999). Gender differences in rape reporting. Sex Roles, 40, 979-990. doi:10.1023/A:1018837524712

Pratt, C., \& Deosaransingh, K. (1997). Gender differences in homicide in contra costa county, California: 1982-1993. American Journal of Preventative Medicine, 13, 19-24.

Quinsey, V. L., \& Upfold, D. (1985). Rape completion and victim injury as a function of female resistance strategy. Canadian Journal of Behavioural Science, 17, 40-50. doi:10.1037/h0080128

Rogde, S., Hougen, H. P., \& Poulsen, K. (2000). Homicide by sharp force in two Scandinavian capitals. Forensic Science International, 109, 135-145. doi:10.1016/S0379-0738(99)00230-3

Ruback, R. B., \& Ivie, D. L. (1998). Prior relationship, resistance, and injury in rapes: An analysis of crisis center records. Violence and Victims, 3, 99-111.

Safarik, M. E., Jarvis, J. P., \& Nussbaum, K. E. (2002). Sexual homicide of elderly females: Linking offender characteristics to victim and crime scene attributes. Journal of Interpersonal Violence, 17, 500-525. doi:10.1177/0886260502017005002

Safarik, M. E., \& Jarvis, J. P. (2005). Examining attributes of homicides: Toward quantifying qualitative values of injury severity. Homicide Studies, 9, 183-203. doi:10.1177/1088767905277144

Salfati, C. G., \& Taylor, P. J. (2006). Differentiating sexual violence: A comparison of sexual homicide and rape. Psychology, Crime \& Law, 26, 107-125. doi:10.1080/10683160500036871

Salfati, C. G., \& Canter, D. V. (1999). Differentiating stranger murders: Profiling offender characteristics from behavioural styles. Behavioural Sciences and the Law, 17, 391-406. doi:10.1002/(SICI)1099-0798(199907/09)17:3<391::AID-BSL352>3 .0.CO;2-Z

Salfati, G. C. (2000). The nature of expressiveness and instrumentality in homicide: Implications for offender profiling. Homicide Studies, 4, 265-293. doi:10.1177/1088767900004003004

Simon, T. R., Crosby, A. E., \& Dahlberg, L. L. (1999). Students who carry weapons to high school. Journal of Adolescent Health, 24, 340-348. doi:10.1016/S1054-139X(98)00121-9

Smith, J. (2003). The nature of personal robbery. Home Office Research Study 254. London: Home Office.

Sorenson, S. B., \& Wiebe, D. J. (2004) Weapons in the lives of battered women. American Journal of Public Health, 94, 1412-1417. doi:10.2105/AJPH.94.8.1412

Stueve, A., \& Link, B. G. (1997). Violence and psychiatric disorders: Results from an epidemiological study of young adults in Israel. Psychiatric Quarterly. Special Issue: The Ninth Annual New York State Office of Mental Health Research Conference, 68, 327-342.

Swanson, J. W., Swartz, M. S., \& Van Dorn, R. A. (2006). A National Study of Violent Behavior in Persons with Schizophrenia. Archives of General Psychiatry, 63, 490-499. doi:10.1001/archpsyc.63.5.490

Thurnherr, J., Michaud, P. A, Berchtold, A., Akre, C., \& Suris, J. C. (2009). Youths carrying a weapon or using a weapon in a fight: What makes the difference? Health Education Research, 24, 270-279. doi:10.1093/her/cyn017

Thompson, M. P., Saltzman L. E., \& Bibel, D. (1999). Applying NIBRS data to the study of intimate partner violence: Massachusetts as a case study. Journal of Quantitative Criminology, 15, 163-180. doi:10.1023/A:1007522721430

Vinogradov, S., Dishotsky, N. I., Doty, A. K., \& Tinklenberg, J. R. (1998). Patterns of behavior in adolescent rape. American Journal of Orthopsychiatry, 58, 179-187. doi:10.1111/j.1939-0025.1988.tb01579.x

Wells, W., \& Horney, J. (2002). Weapon effects and individual intent to do harm: Influences on the escalation of violence. Criminology, 40, 265-296. doi:10.1111/j.1745-9125.2002.tb00957.x

Woodhams, J., Gillett, R., \& Grant, T. (2007). Understanding the factors that affect the severity of juvenile stranger sex offenders: The effect of victim characteristics and number of suspects. Journal of Interpersonal Violence, 22, 218-237. doi:10.1177/0886260506295349

Wintemute, G. J., Drake, C. M., Beaumont, J. J., Wright, M. A., \& Parham, C. A. (1998). Prior misdemeanour convictions as a risk factor for later violent and firearm-related criminal activity among authorized purchasers of handguns. The Journal of the American Medical Association, 24, 2083-2087. doi:10.1001/jama.280.24.2083 